\title{
PHILOLOGY
}

\section{THE MOTIVE OF ASCETICISM IN EMILY DICKENSON'S POETRY}

\author{
Abdurahmanova Saadat Khalid, Ph.D. \\ Odlar Yurdu University, Baku, Azerbaijan \\ DOI: https://doi.org/10.31435/rsglobal_wos/31012020/6880
}

\section{ARTICLE INFO}

Received: 25 November 2019

Accepted: 12 January 2020

Published: 31 January 2020

\section{KEYWORDS}

spiritual asceticism, psychological portrait, transcendentalism, Emily Dickenson's poetry.

\begin{abstract}
This paper is an attempt to analyze the poetry of Miss Emily Dickinson (1830-1886) contributed both American and World literature in order to reveal the extent of asceticism in it. Asceticism involves a deep, almost obsessive, concern with such problems as death, the life after death, the existence of the soul, immortality, the existence of God and heaven, the meaningless of life and etc. Her enthusiastic expressions of life in poems had influenced the development of poetry and became the source of inspiration for other poets and poetesses not only in last century but also in modern times. The paper clarifies the motives of spiritual asceticism, self-identity in Emily Dickenson's poetry.
\end{abstract}

Citation: Abdurahmanova Saadat Khalid. (2020) The Motive of Asceticism in Emily Dickenson's Poetry. International Academy Journal Web of Scholar. 1(43). doi: 10.31435/rsglobal_wos/31012020/6880

Copyright: (C) 2020 Abdurahmanova Saadat Khalid. This is an open-access article distributed under the terms of the Creative Commons Attribution License (CC BY). The use, distribution or reproduction in other forums is permitted, provided the original author(s) or licensor are credited and that the original publication in this journal is cited, in accordance with accepted academic practice. No use, distribution or reproduction is permitted which does not comply with these terms.

Problem statement. Emily Dickenson possessing distinguishing place in the XIX century American poetry with her incomparable lyricism has focused her readers' attention over philosophical and psychological aspects of life, primarily on nature, life, the world of spirit, death and immortality. Emily Dickenson's brilliance of writing style and integrity of vision made her one of America's most famous poets all over the world. As researchers George and Barabara Perkins wrote in "The American Tradition in Literature" of Emily Dickenson that she was "incomparable because her originality sets her apart from all others, but her poems shed the unmistakable light of greatness" (1, p.972). Emily's truth-seeking and eager of spiritual asceticism were a moral quest that conquered her inner world blossoming through her poems.

Most poems written by Emily Dickenson are distinguished by a vivid reflection of the psychological and spiritual manifestation of the inner world of images, simplicity, a lyricism of nature, and a strong sense of imagination.

Her poetry has a unique place and role in the creation of the theme of nature and the description of human emotions, feelings and emotions through natural events.

Her poems can be divided into thematic themes which express loneliness, immortality, naturehuman unity and asceticism strongly. The poetess has written her works on each of these themes, throughout the peculiarities of her own world. The poems on love especially are full of ascetical elements. Aestheticism includes abstinence from sensual pleasures, often for the purpose of gaining spiritual goals. The ascetical elements in her poetry were influenced by the poetess's life experiment especially by her ill-fated loves. Because it was her ill-fated love that made her famous and immortal. Emily Dickenson wrote, thought even felt differently than the female writers or poets contemporary to her. The researcher Petrino Elizabeth notes that "Dickenson employs social and linguistic strategies of limitation in order to test the boundaries of existence. Viewed against the shared culture and literary tradition of the nineteenth-century women writers, Dickenson creates a new, powerful means of expression within the prescribed limits" $(2$, p.4). 
The theme of death, life after death occupies special place in E. Dickenson's poetry. The poetess's poems on death are influenced by her personal perception, past experience that life "gifted" her and religious belief. Occupied by these themes Emily Dickenson feels ascetical and thinks have nothing to do with the reality full of violence, hypocrisy, injustice. "Sandra Gilbert and Susan Gubar assume that Dickenson, like an actress, wore white to play a role, "impersonating simultaneously a "little maid" in white, a fierce virgin in white, a nun in white, a bride in white, a madwoman in white, a dead woman in white, and a ghost" (3, p.40).

The investigations have shown that Emily Dickinson, one of the most prominent representatives of the XIX century American literature, wrote about 1800 poems, and about 12 of them, and due to some sources 10 poems (the poem "Success is counted sweetest" was published twice in separate collections) and a letter were published (4).

The new trend of transcendentalism, founded by Ralph Waldo Emerson in the second half of the XIX century American literature, influenced on Emily Dickinson's creativity. Generally, the last representative of the philosophical poetry of transcendentalism, beginning with Ralph Waldo Emerson in the United States literature, was Emily Dickinson. Emily Dickenson's poetry is the personification of the literary trend - transcendentalism. The poetry of Dickenson ponders and appreciates the ways of coexistence of human nature with the world exhibiting the spiritual hunger of the period she lived and expresses her curiosity towards human experience.

Transcendentalism has some similar philosophical ideas with Sufism, trend of the eastern world. "Transcendentalism is fundamentally an intuitionism, a belief that Truth can be intuitively perceived by higher Reason that this intuition precedes and invigorates all religious awareness, and that it can penetrate the various forms of world religions, extracting from them their essence" (5, p. 13).

These two trends, which promote almost the same idea, unite their representatives in the same mind, regardless of their time, place, or era. "Both of them show disgust in the prevailing and orthodox set of systems whether religious or social. The very interesting point to note is that there is nothing like escapism in both of these ideologies though both take nature as their main source. Both of them believe in the change from within. Both these ideologies seem striving for peace and harmony for progress and prosperity. Both consider recognition of human conscious, reckoning of the individuality, self-esteem, selfreliance as the pillars on which the castle of overall changes stand. In a nut shell both of them have such sublimely embraceable features that make them look like twin ideologies" (6, p. 28).

The trend of transcendentalism is based on a fundamental belief that recognizes the unity of the world and God. The idea of each individual's soul's having the same spirit as the world, and the world's being microcosmos were accepted.

Sufism was a vicious rebellion against materialism and orthodoxy. Just as transcendentalism denies the church and the clergymen, Sufism appreciates the spiritual value of religion, not religious books or mullahs (Mullah is the name given to teachers or scholars of Islamic learning or the leaders of mosques). Both tendencies claimed that love for God was in the individual's heart, it can't be found in mosques or churches, mullahs or monks.

Purpose of the article. The main objective of the research is to analyze the artistic expression of emotions and feelings, thoughts and views that permeate the inner world of the human being and cause them to think deeper and to investigate the motive of asceticism in the poems of Emily Dickinson, a distinguished representative of the second half of the XIX century of modern American poetry, whose style and originality differ from all poets of the time.

Presenting main material. The work of Emily Dickinson (1830-1886), one of the most prominent representatives of american feminist literature in the second half of the XIX century, which is only 56 years old, is of great importance. Emily Dickenson's poetry, whose creativity has benefited from both Puritanism and Transcendentalism, differs from other poets and writers in terms of ideas. While the features of Puritanism may be found in the early stages of Emily Dickinson's career but the other stage is enriched with Transcendentalist ideas.

The idea of Puritanism is a trend that comes from Europe and is linked to religion. Supporters of this trend believed that "some people determined by destiny" would meet God in the Hereafter, and that only these "chosen ones" would be in contact with God. The Puritans were concerned that scientific knowledge would drive people away from the church.

Transcendentalists do not rely on traditional beliefs, signs, omens, but on knowledge formed from individual thought and mentality. They were skeptical of all religions, believing that God was in 
the heart of every human being, and that churches were simply the obstacles on the way of enlightening people. The superstition, the result of much more belief deprives people of the reality, healthy thinking and pleasures of life.

Ralph Waldo Emerson, founder of Transcendentalism in America, wrote the first book, "Nature", written in 1836, embodies the basic concept of transcendentalism. In 1842-1844, Emerson, with the help of his associates, published a Transcendentalist journal called "The Dial", and Thoreau Henry David, a close friend and co-founder, was appointed editor of the magazine. Although the tendency of transcendentalism (1840-1855) wasn't long-lived, it could leave indelible traces in the writings of such poets such as Emily Dickenson, Walt Whitman.

Apparently, Benjamin Newton, one of the first teachers of Dickinson, helped her to get closer to the world and God, to be a little further away from the material world and to realize her own inner world, philosophical-psychological views. Emily Dickenson called her teacher, Benjamin Newton, "a friend who taught me immortality", who taught her to understand thinking deeply of the frailty of the world and ways to connect with the world of spirit. Lawyer Benjamin Franklin Newton was a student of E. Dickenson's father, the first teacher of E. Dickinson. He helped Emily to develop her literary skills and had a profound influence on her religious ideas. Newton believed that Emily was a great poetess and encouraged her to write more. That's why Emily Dickenson wrote her letters and poems dedicating to her so called "my first friend", my "dead teacher" (M.265), "My father's lawyer student" (L750), "My dearest elder brother", "friend who taught me immortality".

Due to Emily Newton came to Amherst in the fall of 1847. Like many other students of Edward Dickinson, he becomes a regular guest of the family and soon becomes friends with Emily, who has just been enrolled in Mount Holyoke Female Seminary. Even though Emily tried to hide her interest in poetry, people around her knew that she was writing poetry. In fact, these poems were in a state of readiness. Emily Dickinson wrote poems on separate sheets, sewed them with her own hands, and kept them in chapters one, two, three, and other. Before she died, Emily instructed her sister, Lavinia, to burn them after her death. However, Lavinia sees these manuscripts as a great work and does not follow her sister's will. She discovers a collection of 1,800 poems, later called "Fascicles" in 40 chapters, and decides not to destroy them. Lavinia asks Emily's closest friend and her brother's wife Susan, to prepare them for printing. However, seeing that Susan could not do it, after 2 years Lavinia gives them to Mabel Loomis Todd for coping and editing. And so Emily Dickinson's first book of poems was published in 1890 with some modifications under the direction of Thomas Higginson and by Mabel Loomis Todd. This book was the first meeting of American readers and the literary community in general with Dickinson's creativity. Thus, the poetess's poems that she wrote throughout her life were "discovered" after her death, becoming really contribution to American literature.

This outstanding representative of American literature is the author of about 1800 poems on different philosophical-psychological themes. Although women writers at that time wrote especially about domestic life, Emily Dickinson's inspirational and spiritual themes made her the greatest female poetess in American literature. What makes her so special is her unique feeling, thinking and writing style. In poetess's works, it is possible to feel the shivering of a soul that is not satisfied with life but can no longer stand it.

Surgeons must be very careful

When they take the knife!

Underneath their fine incisions

Stirs the Culprit - Life! (7)

Loss of loved ones served as a background for her to live her rest of life lonely. Death would have been much more enjoyable to him than to live.

Because the rest of her life is spent with memories of the past, not of the future, it has become so difficult to accept what is happening in her life as she has built the future under past memories.

In Dickinson's poems about death such as "A Clock stopped", "He fumbles at your Souls", "Death is like the Insect", "Because I Could Not Stop for Death", we can see that the author glorifies death with a special talent. It is clear from Dickinson's writings that she was disappointed in life and was tired of it. Facing death of her dearest ones made her personalize Death in her poems. Emily Dickenson is an isolated, never married, monotonous woman and a poet who always thinks optimistically about her fate with her religious beliefs and feels close to death. In "I heard a Fly buzz - when I died -", the author presents the torture of dying person in his deathbed and the fly symbolizes the impact of death on life. 
"I heard a Fly buzz - when I died -"

With Blue- uncertain-stumbling Buzz-

Between the light-and me-

And then the Windows failed-and then

I could not see to see- (7)

The fly represents violence, cruelty because it has the peculiarity to hurt people and make them cry. These lines show us not only the death moment and he torture of human but also the world of Emily Dickenson involved to asceticism.

The window is closed, the sound of the fly is interrupted, and the hero passes away. Dickinson, who had been enjoying life for many years and who had been waiting for death to be his friend, got aware that she did not want to die in the last minutes of her life, and that death has interrupted her life. Another poem of the poetess on the same theme draws the reader's attention with its deep thought and idea. The heroes of the poem "I died for Beauty-but was scarce", woman and man were described chatting with each other at the tomb after their death.

And so, as kinsmen met a night,

We talked between the rooms.

Until the moss had reached our lips,

And covered up our names. (7)

The last lines of the poem are perhaps the most interesting irony of poetess used in the poems on death. We have been talking for a long time until "the moss has reached our lips, and covered up our names" - that is, mosses, reaching out to our mouths, preventing us from speaking and covering our names in the graves. This, in turn, means that until we are forgotten, we will just lie in our graves but live in the hearts. So many honorable, privileged, noble, or poor or disrespectful people are in the grave, the same time is coming, and everyone is forgotten. It is very interesting that the only alive symbol of life was blowing fly in her poem "I Heard a Fly buzz - when I died" but in "I died for Beauty-but was scarce" the symbol of life is the bush described at the end of the poem.

In her poem "Because I Could Not Stop for Death" the poetess uses metaphors to emphasize the process of death. "Eternity is the standpoint that life continues even after the physical death, because of the immortality of the soul. In the poem "Because I Could Not Stop for Death," the poet uses metaphor and a calm tone to describe the process of death and entry into new eternal life (8). In literature, metaphors are used to compare different aspects that have similar features to bring out the intended meaning of the text. In the first stanza, Dickinson uses carriage as a metaphor where she indicates that it is driven by death, accompanied by immortality (9).

Because I could not stop for Death-

He kindly stopped for me-

The Carriage held but just Ourselves-

And Immortality (7)

In this poem we see two characters-woman and her financer Death who came to take her away from this life to another bidding farewell to everything she used to see every day.

Researcher Gerhardt rightly claims that "although death is a sad event that causes emotional grief to the bereaved, Dickinson presents it as a normal and adventurous process. The speaker describes death as civil and patient, eliminating the negative aspects that it is associated with" (10).

Because of the loss of dearest ones whom she loved so much in her life, death has become the focus of Dickinson's poems. We are not mistaken even if we claim that she lived as a lifeless dead man.

According to David Porter, Dickinson describes the "aftermath" of her crucial experiences in the actual life (11, p. 9). Most experience referred to in a poem is not the experience itself, but is its effects.

Emily Dickenson, who is home-locked, isolated from society, and always dressed in white, wrote of the most shocking death in her life. The researcher Sandra Giblert and Susan Gubar wrote of E. Dickenson that “...by literally and figuratively impersonating 'a woman-white,' Dickinson wove her life into a gothic 'Yarn of Pearl' that gave her exactly the 'Amplitude' and 'Awe' she knew she needed in order to write great poetry" (12, p. 586).

The asceticism of Emily Dickenson's poems is directly related to her inner psychological state. The death of her closest ones pushed Emily Dickenson to pursue a deeper meaning in life, not to be shaken in it. Emily Dickenson's death poems highlight her in a special way, with a special passion. 
Poems such as "I Could Not Stop for Death", "I Heard a Fly buzz - When I died", or "I died for beauty" are also some of the poetess's most famous poems written in this thread. In each of her poems, she approached the same topic differently.

Emily Dickinson's poems on life are also in the center of interest for ex. "I Have No Time to Hate":

I had no time to Hate, because

The Grave would hinder Me,

And life was not so Ample I

Could finish Enmity.

Nor had I time to Love, but since

Some Industry must be,

The little Toil of Love, I thought,

Was large enough for me. (7)

Spending time with hatred, enmity, and revenge, one's life will pass through intrigue, strife, and resentment. In the end, when one looks back, and will realize that all this is empty and meaningless, and as a chance one will see that life, given to enjoying the beauty and enjoying life, is worthless.

That is, life is so short; it destroys and ends the love and hate we have in this world. If life were long, man would be full of both love and hate. In such a short life, the poetess still prefers to love. After all, she must have a feeling! Hatred and love are feelings within the power of man. Emily Dickinson states that hatred is not a matter of hatred, enmity, feud, but merely an emotion, a feeling that one must live and taste.

There is so much refinement and purity in the soul of the poetess that she is able to move out of this world without the pleasure of these feelings. And one of the highlights of this poem is that the poem was written in the past based on English grammar. It was as if the poet had written this poem after her passing away.

Emily Dickinson' poems has been translated into many languages, has reached the hearts of millions of readers and has become a readable book in innumerable homes posthumously. Tasting loneliness in her life, she generalized, and humanized.

"It is clear that Dickinson's poetry foreruns all these characteristics of modern poetics. It might be said that she has been discovered as the founder of another tradition of American poetry that sets "language prior to reality" (13, p. 261). As Emerson, W. Whitman, Emily Dickenson believed that the poems are forms of the vocal expressions breathed forth from their bodies expressing their thought and feelings.

Conclusions. The idea that man is an eternal soul and a temporary body is a new breath in Emily Dickenson's poetry. Being literary motivation

E. Dickinson's lyric is a poem that is addressed not only to its own times, but to all periods and to the whole of mankind. Poetry does not depend on classical poetry traditions, because Dickenson is more important in conveying the meaning, she does not have the form of captivity in her thoughts, breaks the "fetter" of the form for the sake of content, and the reader does not feel it. Content is the search for higher truths that come from the depths of the heart that make human beings closer to their Creator-God the Almighty.

Dickinson is generally known as the author of various poems in world literature. Her spirit of illusion, combined with the shades of rich imagination, finds a full embodiment of the expressive qualities in her poems, creating interesting emotions for the reader. Of course, each writer has a wide range of meanings and approaches to a lyrical, multidisciplinary theme and different characters. But Emily Dickinson is a genius poetess who is capable of expressing the feelings of women. Being a woman she had the privilege to feel the same way as the women feel, but not think. Because her thoughts full of deep psychology and philosophy made her differ from other women. The portraits of women described by her pen are remembered for their mysterious appearance, rich romance, and at the same time their simplicity, naturalness, feelings and thoughts. While reading her poems one can feel the loneliness, asceticism, pain that the author felt writing it.

The dogma that society puts on a woman can't ban Dickenson's pen to write. Dickenson's poems are a reflection of her inner world on paper. Traditional styles inherent in a number of her poems have been replaced by contemporary forms of creativity. This is one of the features that distinguish her from other female writers of the world of different eras. 


\section{REFERENCES}

1. Perkins G., Perkins B. The American Tradition in Literature. 9th ed. Boston: McGraw,1999.

2. Petrino A. Elizabeth. Emily Dickenson and Her Contemporaries. United States of America: University Press of New England, 1988.

3. Farr J. The Passion of Emily Dickinson. Harvard University press, 2004, 385p.

4. Anderson C. Emily Dickinson's Poetry: Stairway of Surprise. New York: Holt, Rinehart and Winston, 1960.

5. Versluis A. Religion in America: American Transcendentalism and Asian Religions. Oxford University Press. Versluis, 1993

6. Chaudhary S.L. A Comparative Study of Oriental Sufism and American Transcendentalism. International Journal of Education and Social Science. Vol. 3 No. 2; February 2016

7. Emily Dickinson Poems. http://www.emilydickinsonpoems.org/Emily_Dickinson

8. Dickinson E., Howe, S. (2004). Because I could not stop for Death. ProQuest LLC.

9. Green J. W. Beyond the Good Death: The anthropology of modern dying. University of Pennsylvania Press. 2012.

10. Gerhardt C. "Often seen-but seldom felt": Emily Dickinson's Reluctant Ecology of Place. The Emily Dickinson Journal, 2006, 15(1), 56-78p.

11. Porter D. Dickinson: The Modern Idiom. Cambridge: Harvard University Press, 1981.

12. Gilbert S. M., Gubar S. "A Woman-White: Emily Dickinson's Yarn of Pearl," in The Madwoman in the Attic. New Haven: Yale University Press. 1979

13. Ruland R., Bradbury M. From Puritanism to Postmodernism: A History of American Literature. 1991. New York: Penguin Books, 1992. 